\title{
REVIEW
}

\section{Hypertension in the newborn baby}

\section{Watkinson}

Hypertension is rare in the newborn infant. It has a cumbersome definition and diagnosis, and screening is not justified using present definitions and technology. Thresholds for starting antihypertensive treatment in the first month of life are not clear, and the treatment is difficult, with idiosyncratic responses to drugs in neonates with varying renal and hepatic function.

$\mathrm{N}$ eonatologists diagnose and treat hypotension most days of their lives, but rarely diagnose hypertension in the newborn baby. Why? The definition of hypertension is based on centiles from population data. ${ }^{12}$ There are as many babies below the 5th centile as there are above the 95th centile, but only the former receive much attention. This paradox is heightened by recommendations that universal screening of blood pressure in neonates is not warranted. ${ }^{3}$ Therefore, blood pressure is measured only in the $7-8 \%$ of newborn babies admitted to neonatal unitsusually screening for hypotension-and in another $1-2 \%$ of babies with a recognised cardiovascular or renal abnormality.

\section{Neonatologists diagnose and treat hypotension most days of their lives, but rarely diagnose hypertension in the newborn baby.}

\section{DEFINITION}

Hypertension in children and infants is diagnosed as a systolic and/or diastolic pressure $\geqslant 95$ th centile for age and sex on three separate occasions, but in the newborn only systolic values are used. ${ }^{1}$ This epidemiological definition based on centiles has been criticised as having no biological meaning for children because it was introduced to assess adults and essential hypertension.

\section{MEASUREMENT}

The baby should be quiet, and not feeding; systolic pressure is $5 \mathrm{~mm} \mathrm{Hg}$ lower in sleeping babies. In newborns, conventional sphygmomanometry is not recommended because the Korotkoff sounds cannot be heard reliably. ${ }^{2}$ Instead Doppler ultrasound, pulse oximetry, or oscillometry are used. The pulse oximetry technique uses the disappearance and reappearance of the plethysmographic waveform of a pulse oximeter as the cuff is inflated and deflated around systolic pressure. ${ }^{6}$ It has been used in infants in intensive care with distinct oximetry waveforms, but further work is needed to support its wider use. Oscillometric manometers are the most widely used instruments in clinical practice, but are less accurate than either Doppler or pulse oximetry techniques when compared with the gold standard of intra-arterial pressures. ${ }^{67}$ For non-invasive measurements, the cuff bladder should cover $80-100 \%$ of the upper arm circumference and its width should be $40 \%$ of that same circumference.

\section{NORMAL DATA}

The American Second Task Force on Blood Pressure Control in Children ${ }^{1}$ incorporated data from over 70000 American and British children $^{58}$ into its centiles. More recently, two large British studies produced reference ranges for preterm babies, recording mean blood pressure using indwelling arterial catheters, ${ }^{9}$ and systolic pressure by Doppler ultrasound. ${ }^{7}$ Neither reported the 95th centiles, the closest being the 97th centiles shown graphically in the latter, which also included data on term babies. Table 1 summarises these findings.

\section{SCREENING AND TRACKING}

The original criteria of Wilson and Jungner for disease screening programmes have been reenunciated by the National Screening Committee. ${ }^{10}$ In brief, the disease itself should be an important problem, with a known natural history that progresses from a latent to a declared phase with a detectable risk factor or disease marker in the former. There should be an effective treatment. The test should be validated, simple, safe, and precise with an agreed cut off value. It should be acceptable to the population being screened and be economically balanced. Hypertension in the newborn does not fulfil several criteria. The difficulty and time costs of three separate accurate measurements do not equate to "a validated simple, safe, and precise screening test". Also, neonatal hypertension does not "progress from a latent to a declared disease". Tracking is the concept that a child will grow along (track) his blood pressure centile into adulthood-that is, a child with a blood pressure on the higher centiles will develop into a similarly placed adult. This correlation increases with age, but in the Brompton study "at ages 4 days, 6 weeks and 6 months blood pressures were in effect not correlated with blood pressures later in life."11

\section{INCIDENCE AND AETIOLOGY}

The reported incidence of hypertension in neonates varies from $0.2 \%$ in the oft quoted data from Ingelfinger for healthy newborns, ${ }^{12}$ up to $2.6 \%$ in babies after neonatal intensive care, ${ }^{13}$ and $40 \%$ in patients with chronic lung disease. ${ }^{14}$ However, many reports used non-standard definitions, had a biased selection of babies, and an incomplete 
Table 1 95th and 97th centiles for systolic blood pressure in babies

\begin{tabular}{|c|c|c|c|c|c|}
\hline \multirow[b]{2}{*}{ Study } & \multirow[b]{2}{*}{ Technique } & \multirow[b]{2}{*}{ Gestation } & \multirow[b]{2}{*}{ Age } & \multicolumn{2}{|c|}{ Systolic blood pressure $(\mathrm{mm} \mathrm{Hg})$} \\
\hline & & & & 95th centile & 97th centile \\
\hline American Academy of Pediatrics 2nd task force' & First auscultation or Doppler & Term & $\begin{array}{l}\text { Day } 1 \\
\text { Day 8-30 }\end{array}$ & $\begin{array}{l}96 \\
104\end{array}$ & \\
\hline Brompton $^{5}$ & Mean of 3 Dopplers & Term & $\begin{array}{l}\text { Day } 4 \\
6 \text { weeks }\end{array}$ & $\begin{array}{l}95^{*} \\
113^{*}\end{array}$ & \\
\hline Northern Neonatal Nursing Initiative ${ }^{7}$ & Mean of 3 or more Dopplers & Term & $\begin{array}{l}\text { Day } 1 \\
\text { Day } 10\end{array}$ & & $\begin{array}{l}82 \\
111\end{array}$ \\
\hline Northern Neonatal Nursing Initiative & Mean of 3 or more Dopplers & $\begin{array}{l}24 \text { weeks } \\
28 \text { weeks } \\
32 \text { weeks } \\
36 \text { weeks }\end{array}$ & $\begin{array}{l}\text { Day } 1 \\
\text { Day } 10 \\
\text { Day } 1 \\
\text { Day } 10 \\
\text { Day } 1 \\
\text { Day } 10 \\
\text { Day 1 } \\
\text { Day } 10\end{array}$ & & $\begin{array}{l}57 \\
71 \\
62 \\
83 \\
67 \\
94 \\
74 \\
104\end{array}$ \\
\hline
\end{tabular}

Table 2 Review of hypertension in neonates on or recently discharged from neonatal units

\begin{tabular}{|c|c|c|c|c|c|c|c|c|c|c|c|}
\hline \multirow[b]{2}{*}{ Reference } & \multirow[b]{2}{*}{ Year } & \multirow[b]{2}{*}{$\mathrm{n}$} & \multirow[b]{2}{*}{$\begin{array}{l}\text { Postnatal } \\
\text { age of } \\
\text { diagnosis } \\
\text { (days) }\end{array}$} & \multirow[b]{2}{*}{$\begin{array}{l}\text { Odds ratio for } \\
\text { hypertension } \\
\text { UAC } \vee \text { no UAC } \\
\text { (stated or } \\
\text { calculable) }\end{array}$} & \multicolumn{7}{|c|}{ Percentage of cases in series } \\
\hline & & & & & $\begin{array}{l}\text { Umbilical } \\
\text { artery } \\
\text { catheter } \\
\text { (UAC) }\end{array}$ & $\begin{array}{l}\text { Aortic or } \\
\text { renal artery } \\
\text { thrombus } \\
\text { or embolus }\end{array}$ & $\begin{array}{l}\text { Renal } \\
\text { vascular }\end{array}$ & $\begin{array}{l}\text { Other } \\
\text { renal }\end{array}$ & $\begin{array}{l}\text { Neurogenic } \\
\text { tumour }\end{array}$ & Coarctation & $\begin{array}{l}\text { No } \\
\text { cause }\end{array}$ \\
\hline \multicolumn{12}{|c|}{ Neonatal unit stay } \\
\hline Adelman ${ }^{24}$ & 1978 & 9 & 10 & 4.8 & 89 & 89 & & & & & \\
\hline Skalina ${ }^{17}$ & 1986 & 20 & 13 & - & 80 & 65 & & 10 & 0 & 5 & \\
\hline Buchi ${ }^{15}$ & 1986 & 53 & 11 & - & 75 & 9 & 6 & 25 & 0 & 4 & 57 \\
\hline Singh ${ }^{16}$ & 1992 & 26 & - & 44 & 77 & 19 & & 27 & 0 & 4 & 15 \\
\hline \multicolumn{12}{|l|}{ Follow up } \\
\hline Sheftel ${ }^{23}$ & 1983 & 7 & 103 & 1.0 & 43 & & & 14 & 14 & 14 & 57 \\
\hline Friedman $^{13}$ & 1987 & 17 & 105 & 1.1 & 29 & 6 & & 12 & 6 & 6 & 71 \\
\hline $\operatorname{Arar}^{28}$ & 1994 & 12 & - & - & - & 50 & 8 & 25 & 8 & 8 & 0 \\
\hline
\end{tabular}

follow up. One group concluded that "at most only $1 \%$ of children have blood pressures consistently and appreciably above the 95th centile for single measurements". ${ }^{2}$

Table 2 shows data from some papers on hypertension in babies on or recently discharged from neonatal units. Three American series reported incidences of $0.7 \%, 0.81 \%$, and $2.0 \%$ of hypertension on their neonatal intensive care units, but different thresholds for diagnosing hypertension were used. ${ }^{15-17}$ Some $80 \%$ of their hypertensive babies had had an umbilical artery catheter in situ before the hypertension. This was a risk factor when hypertension was diagnosed in the first 2 weeks of life, but not when it was diagnosed at follow up (table 2). Improved catheter design and the use of heparin have reduced but not eradicated this problem.

Babies with chronic lung disease can become hypertensive. ${ }^{14}$ Dexamethasone treatment of chronic lung disease raises systolic pressure by a median of $27 \mathrm{~mm} \mathrm{Hg}$ and this usually resolves two weeks after treatment is stopped. ${ }^{18}$ Pain, patent ductus arteriosus, extracorporeal membrane oxygenation (ECMO), ${ }^{19}$ other renal causes, endocrinological disorders, maternal drug abuse in pregnancy, ${ }^{20}$ tumours, and neurological problems should all be considered. ${ }^{21}$

\section{INVESTIGATION}

Recognition of specific conditions such as those listed above may limit the need for further tests. The baby should be re-examined with particular attention to systolic pressures in the upper and lower limbs, murmurs, bruits, and abdominal masses. Signs of end organ damage should be sought; retinopathy, encephalopathy, left ventricular hypertrophy, haematuria, and proteinuria must all be considered.

Basic plasma and urine biochemistry should be checked. All hypertensive babies should have an ultrasound scan of the renal tract and suprarenal region, and the abdomen should be radiographed by an experienced paediatric radiologist. Infants who have had an indwelling umbilical artery catheter should have their aortas and renal arteries imaged, at the very least by ultrasonography, to look for thrombi. ${ }^{22}$ These and renal vein thromboses, congenital abnormalities of the renal tract, obstructive uropathies, parenchymal renal disease, and tumours may be seen. Doppler studies of the renal arteries may reveal stenosis, but branch artery stenosis can be missed. The brain should be scanned for intracranial haemorrhage and cerebral oedema. Renograms, plasma renin activity, aldosterone, cortisol, and urinary steroid profile, urinary catecholamines, or thyroid function may be appropriate for selected patients.

\section{OUTCOMES}

Neonatal hypertension improves during infancy but the nature of this trend is obscured by variations between studies (table 2). Sheftel et $a^{23}$ diagnosed hypertension in seven (9\%) of 79 preterm babies who had been in intensive care in the first three months after discharge. Follow up was for only 21 weeks, and by then three babies had had surgical treatment, and three of the four "idiopathic" hypertensive babies were 
still receiving antihypertensive drugs. Buchi and Siegler ${ }^{15}$ reported 53 babies who were hypertensive on a neonatal unit by their own lower thresholds of systolic pressures ( $>90 \mathrm{~mm}$ $\mathrm{Hg}$ for term infants and $>80 \mathrm{~mm} \mathrm{Hg}$ for preterm infants). By 12 months, $81 \%$ were normotensive, but two had died from the complications of hypertension, and in four it persisted. Friedman and Hustead ${ }^{13}$ followed 17 (2.6\%) of 654 preterm babies who developed hypertension after discharge from a neonatal intensive care unit. Sixteen were treated, four surgically. Propranolol was the only drug used in all but one, who also had chlorthiazide. All babies were off therapy by 24 months. The earlier group of nine infants of Adelman $e^{2} a^{24}$ developed systolic pressures ranging from 115 to $280 \mathrm{~mm} \mathrm{Hg}$ on a neonatal unit. Eight had renal artery thrombi in association with umbilical artery catheters. One was treated with chlorthiazide alone, seven with hydralazine and methyldopa, and one with propranolol alone. Treatment was discontinued in all by seven months, and they remained normotensive. ${ }^{25}$ These generally favourable outcomes are reassuring, but there are reports of death, heart failure, encephalopathy, and retinal changes in some hypertensive babies. Neonatal hypertension is not entirely benign.

\section{TREATMENT}

\section{First, do no harm!}

The received wisdom is that an asymptomatic neonate with a systolic pressure consistently between the 95th and 99th centiles and with no end organ involvement should be observed but not treated, in the expectation that the hypertension will settle. The dilemma is between "unnecessary" medication and its potential side effects ${ }^{26}{ }^{27}$ for a condition that is likely to resolve, and a fear of sudden life threatening end organ damage secondary to untreated hypertension. The general paediatrician may therefore wish to consult a paediatric nephrologist with greater experience of this problem in young infants, particularly as many cases will be secondary to renal disease. Feld and Waz ${ }^{29}$ advocate treatment if the systolic pressure is above the 99th centile or if there is end organ involvement with a systolic pressure above the 95th centile. The Task Force's 99th centile was $110 \mathrm{~mm} \mathrm{Hg}$ on day 7 of life, ${ }^{1}$ but the 97th centile in a recent study was $111 \mathrm{~mm} \mathrm{Hg}$ on day $10 .^{7}$ There is little if any evidence for a precise, single starting point for treatment. A blood pressure more than $30 \%$ above that expected for age can be considered as a hypertensive emergency. ${ }^{29}$ Empirically therefore one might treat a week old baby with a systolic pressure consistently above 110-115 mm Hg using a Doppler technique, and regard a systolic pressure of $>130 \mathrm{~mm} \mathrm{Hg}$ at that age as a hypertensive emergency.

The received wisdom is that an asymptomatic neonate with a systolic pressure consistently between the 95th and 99th centiles and with no end organ involvement should be observed but not treated, in the expectation that the hypertension will settle.

Treatment should proceed in a stepwise fashion. First reduce or withdraw treatment that may raise blood pressure. Salt or fluid overload must be corrected. If investigations reveal a surgically remediable cause, the timing of surgery depends not just on the nature of the lesion but also on the severity of the hypertension, the benefits and risks of medical treatment, and the age and weight of the baby. If medical treatment is needed, the choice is between five groups of drugs: diuretics, $\beta$-adrenergic blockers, calcium channel blockers, direct peripheral vasodilators, or angiotensin converting enzyme inhibitors. Their use has to be tailored to the cause, to any impending hypertensive crisis, and to the routes available for administration in a particular baby. Many of the drugs are not licensed for children, ${ }^{30}$ have different pharmacokinetics in neonates, and experience with them in this age group is limited. All drugs should be started at their lowest doses, as found in standard texts. ${ }^{30}$

Diuretics increase salt and water excretion, leading to decreased extracellular and plasma volumes. Although compensatory mechanisms come in to maintain sodium homoeostasis and plasma volume may return towards normal, there is a sustained reduction in volume and a modest fall in blood pressure. ${ }^{31}$ Unless a specific problem with high volume hypertension is recognised, their use in neonatal hypertension is limited. Indeed, if volume overload is not present, they may contribute to a hypotensive crisis if used with other antihypertensive drugs.

Propranolol has the advantage of being the most extensively used $\beta$-blocker in neonates with hypertension, and has a low incidence of side effects. Labetolol blocks both $\beta$ and $\alpha$ receptors, although it is eight times more potent against the former. Pure $\alpha$-adrenergic antagonists are rarely used in neonatal hypertension.

Nifedipine is the type II calcium channel blocker that has been used most in babies. It has a vasodilator action that lowers peripheral vascular resistance. Hydralazine and minoxidil act directly on the vascular smooth muscle to reduce peripheral vascular resistance. Hydralazine is the first choice clinically as the more potent minoxidil has a number of adverse effects, and is reserved for those with refractory hypertension. All the vasodilators may initially cause an increase in heart rate and cardiac output and flushing.

Captopril, an angiotensin converting enzyme inhibitor, appears to be more potent and longer acting in the neonate than older children. Doses as low as $10 \mu \mathrm{g} / \mathrm{kg}$ (a tenth of the normal low starting dose) may be effective. Renal vascular resistance is high in neonates, hence the effects of angiotensin converting enzyme inhibitors are more pronounced. If renal vascular disease is suspected, its use should be avoided until it is clear that the renal vasculature is normal. Neurological complications $^{26}$ and oliguria ${ }^{27}$ have been reported after administration of captopril to neonates and it should be used cautiously only after an initial test dose.

In a hypertensive crisis, the intravenous drug of choice is labetalol or hydralazine. These can be titrated against the blood pressure, which may begin to fall within an hour of administration. Some advocate diazoxide but the concern in the neonate is to avoid too rapid and too great a fall in pressure with consequent cerebral underperfusion. Sodium nitroprusside is a difficult drug to use, but has the advantage of a very short half life, so its effect can be quickly reversed if the pressure falls too far, or after the introduction of other drugs. ${ }^{31}$

\section{SUMMARY}

Hypertension is rare in the newborn infant. It has a cumbersome definition and diagnosis. Screening is not justified using present definitions and technology. There has been little work in the 1990s on hypertension in extremely preterm babies. Thresholds for starting antihypertensive drug treatment in the first month of life are unclear and debatable. Treatment is difficult, with idiosyncratic responses to drugs in neonates who have varying renal and hepatic function. There is a need to keep registers of babies who are hypertensive in order to audit the outcome of management with or without antihypertensive drugs, and to establish appropriate thresholds for starting treatment.

\section{REFERENCES}

1 Task Force on Blood Pressure Control in Children. Report of the Second Task Force on Blood Pressure Control in Children - 1987. Pediatrics 1987;79: 1-25.

2 de Swiet M, Dillon M, Littler W, et al. Measurement of blood pressure in children: recommendations of a working party of the British Hypertension Society. BM 1989;299:497. 
3 American Academy of Pediatrics. Routine evaluation of blood pressure, hematocrit and glucose in newborns. Pediatrics $1993 ; 92: 474-6$

4 Goonasekera CDA, Dillon M. Measurement and interpretation of blood pressure. Arch Dis Child 2000;82:261-5.

5 de Swiet M, Fayers P, Shinebourne EA. Systolic blood pressure in a population of infants in the first year of life: The Brompton Study. Pediatrics 1980;65:1028-35

6 Langbaum M, Eyal FG. A practical and reliable method of measuring blood pressure in the neonate by pulse oximetry. J Pediatr 1994:125:591-5.

7 Northern Neonatal Nursing Initiative. Systolic blood pressure in babies less than 32 weeks gestation in the first year of life. Arch Dis Child Fetal Neonatal Ed 1999;80:F38-42.

8 de Swiet $M$, Fayers $P$, Shinebourne EA. Blood pressure survey in a population of newborn infants. BM 1976;2;9-11.

9 Cunningham S, Symon AG, Elton RA, et al. Intra-arterial blood pressure reference ranges, death and morbidity in very low birthweight infants during the first seven days of life. Early Hum Dev 1999;56:151-65.

10 National Screening Committee. First Report of the National Screening Committee. London, Department of Health, 1998:www.open.gov.uk/ doh/nsc/nsch.htm

11 de Swiet $M$, Fayers $P$, Shinebourne EA. Blood pressure in the first 10 years of life: the Brompton Study. BM 1992;304:23-6.

12 Inglefinger JR. Hypertension in the first year of life. In: Inglefinger JR, ed. Pediatric hypertension. Philadelphia: WB Saunders, 1982:229-40.

13 Friedman AL, Hustead VA. Hypertension in babies following discharge from a neonatal intensive care unit. Pediatr Nephrol 1987;1:30-4.

14 Abman SH, Warady BA, Lum GK, et al. Systemic hypertension in infants with bronchopulmonary dysplasia. J Pediatr 1984:104:923-31.

15 Buchi KF, Siegler RL. Hypertension in the first month of life. J Hypertens 1986;4:525-8

16 Singh HP, Morrison Hurley R, Myers TF. Neonatal hypertension: incidence and risk factors. Am J Hypertens 1992:5:51-5.

17 Skalina MEL, Kliegman RM, Fanaroff AA. Epidemiology and management of severe symptomatic neonatal hypertension. Am J Perinatol 1986:3:235-9.

18 Smets K, Vanhaesebrouck P. Dexamethasone associated systemic hypertension in low birth weight babies with chronic lung disease. Eur $J$ Pediatr 1996:155:573-75.

19 Sell LL, Cullen ML, Lerner GR, et al. Hypertension during extracorporeal membrane oxygenation: cause, effect and management. Surgery 1987; 102:724-30.

20 Horn PT. Persistent hypertension after prenatal cocaine exposure. J Pediatr 1992;121:288-91.

21 Flynn JT. Neonatal hypertension: diagnosis and management. Pediatr Nephrol 2000;14:332-41

22 Seibert JJ, Taylor BJ, Williamson SL, et al. Sonographic detection of neonatal umbilical artery thrombosis: clinical correlation. Am Roentgenol 1987:148:965-8.

23 Sheftel DN, Hustead V, Friedman A. Hypertension screening in the follow-up of premature infants. Pediatrics 1983;71:763-6.

24 Adelman RD, Merten D, Vogel J, et al. Nonsurgical management of renovascular hypertension in the neonate. Pediatrics 1978:62:71-6.

25 Adelman RD. Long term follow up of neonatal renovascular hypertension. Pediatr Nephrol 1987; 1:35-41.

26 Perlman JM, Volpe JJ. Neurological complications of captopril treatmen in neonatal hypertension. Pediatrics 1989;83:47-52.

27 O'Dea RF, Mirkin BL, Alward CT, et al. Treatment of neonatal hypertension with captopril. J Pediatr 1988;113:403-6.

28 Arar MY, Hogg RJ, Arant BS Jr, et al. Etiology of sustained hypertension in children in the south-western United States. Pediatr Nephrol 1994;8:186-9.

29 Feld GF, Waz WR. Pharmacologic therapy of hypertension. In: Feld GF ed. Hypertension in children. Boston: Butterworth-Heinemann, 1997: 133-78.

30 Royal College of Paediatrics and Child Health. Medicines for children. London: RCPCH Publications, 1999.

31 Sinaiko AR. Pharmacologic management of childhood hypertension. Pediatr Clin North Am 1993:40:195-212.

\section{ADC web submission and review system}

The Editors of $A D C$ are pleased to inform authors and reviewers of its new online submission and review system. Developed by Highwire Press (CA, USA), Bench $>$ Press is a fully integrated electronic system which uses the internet to allow rapid and efficient submission of manuscripts, and for the peer review process to be conducted entirely online. We are the first journal of the BMJ publishing group to go online in this way; the aim, apart from saving trees, is to speed up the frequently frustrating progress from submission to publication.

Authors can submit their manuscript in any standard word processing software. Standard graphic formats accepted include: .jpg, .tiff, .gif, eps, etc. The text and graphic files are automatically converted to PDF for ease of distribution and reviewing purposes. Authors are asked to approve their submission before it formally enters the reviewing process. On approval, the submission is passed to the editor and/or reviewers via the web. All transactions are secure.

To access the system click on "SUBMIT YOUR MANUSCRIPT HERE" on the ADC homepage: http://www.archdischild.com, or you can access the submission site directly at http://submitadc.bmjjournals.com.

We are very excited with this new development and would encourage authors and reviewers to use the system where possible. It is simple to use and should greatly improve on the current peer review process. Full instructions can be found on Bench $>$ Press and ADC online. 